abroad there is an account of the organisation of science in Great Britain with special reference to the aims and objects of the British Association and of the British Science Guild.

\section{Power Production in the United States}

THE chief sources of energy to-day in the United States are coal and petroleum, which between them account for more than 90 per cent of the demand, water power supplying only 10 per cent. A marked change has occurred in the relative proportion of energy obtained from coal and oil in that country over the last two or three decades. According to Messrs. W. S. Hutchinson and A. J. Breitenstein, whereas thirty years ago 91 per cent of the horse power came from coal and only 4 per cent from oil and natural gas, in 1930 horse power from coal had decreased to 60 per cent while that from oil and gas had risen to 31 per cent. It is estimated that by 1950 coal will furnish only 46 per cent of the country's power, while 45 per cent will come from oil and gas, the remaining energy being derived from water power. Consumption of coal in America apparently reached its zenith in 1917, according to Seience Service of Washington, D.C., but from this date decline has been rapid, dropping from $6 \cdot 08$ tons per capita to $4 \cdot 2$ tons in 1930 ; a further drop is forecast for 1950. Although figures, and particularly estimates regarding the relative importance of coal and oil fuels, can be made to be most misleading, this summary of the situation in America, together with the forecast which experts have made, are not without interest and significance in the controversy which is still waging on this very question in Great Britain.

\section{Announcements}

Sir Richard Gregory, BT., editor of Nature, has been elected a fellow of the Royal Society under the provisions of Statute 12, which provides for the recommendation by the Council of "persons, who, in their opinion, either have rendered conspicuous service to the cause of science, or are such that their election would be of signal benefit to the Society".

Brigadier E. E. B. Mackintosh has been appointed director and secretary of the Science Museum in succession to Sir Henry Lyons who is retiring next October.

Prof. Joran HJort will deliver the next Huxley Memorial lecture at the Imperial College of Science and Technology, on May 4, 1934, at 5.30 p.m. The subject of his lecture will be "The Restrictive Law of Population". Prof. Hjort is professor of marine biology in the University of Oslo, and was formerly director of Norwegian Fisheries. He was elected a foreign member of the Royal Society in 1916.

AT a meeting of the Royal Meteorological Society held on June 21, it was announced that the Council had decided to recommend to a special general meeting of fellows the adoption of revised by-laws, whereby the annual subscription would become two guineas as from January 1, 1934, instead of three guineas as at present. It is hoped that as a result there will be an increasing number of new fellows.

The annual conference of the Museums Association will be held at Norwich on July 3-7, under the presidency of Sir Henry Miers. Several papers will be read and two discussions have been arranged, namely, "Provincial Art Galleries" and "The Illustration of Natural Science". A film entitled "The Bittern in Norfolk and other Illustrations of Bird Life", will be exhibited by Lord William Percy. Further information can be obtained from the Local Secretary, Museums Conference, Castle Museum, Norwich.

THE Minister of Health has made Amendment Regulations, to come into force on September 1, to the Public Health (Imported Food) Regulations, 1925 (Statutory Rules and Orders, 1933, No. 347), with explanatory circular (Circular 1325). The principal purpose of the Amendment Regulations is to extend the existing scheme of certification now applied to the importation of any edible part of a pig so that it will apply in the same way to the edible parts of cattle, sheep and goats.

A Supprement to the Times of June 20, entitled a "Gold Number", gives an account of gold from a number of different aspects. It is shown that the pro. duction of gold is in some respects a British Imperial monopoly, the British Empire producing something like 70 per cent of the world's gold output, 50 per cent of this output being due to the Transvaal. The issue is a very complete one and contains information on practically every aspect of gold production and utilisation.

Applications are invited for the following appoint. ments, on or before the dates mentioned:-A lecturer in mechanical engineering at the Municipal Technical College and Junior Technical School at Bolton-The Director of Education, Education Offices, Nelson Square, Bolton (July 7). A head of the Department of Biology at the Cheisea Polytechnic, London, S.W.3-The Principal (July 8). An assistant lecturer in organic chemistry at the University College of North Wales, Bangor-The Registrar (July 10). A demonstrator in zoology at University College, Southampton-The Registrar (July 10). An assistant lecturer in mathematics at King's College, Strand, London, W.C.2-The Secretary (July 10). A junior lecturer in chemistry at The University of Edinburgh-The Secretary (July 10). A librarian and curator of the museum for the Borough of Whitehaven-The Town Clerk, Town Hall, Whitehaven (July 15). An assistant lecturer in physics at the University of Leeds--The Registrar (July 17). An assistant master in machine design, applied mechanics, electricity, etc., at Erith Technical College-The Principal, Erith Technical College, Belvedere. A science master at Eastbourne Tech. nical Institute-The Town Clerk and Secretary, Education Office, Mead's Road, Eastbourne. 